This is an electronic reprint of the original article. This reprint may differ from the original in pagination and typographic detail.

Author(s): Mykkänen, Markus

Title: Digitaalisen vuorovaikutuksen kulttuuri haastaa poliitikoiden viestintäosaamisen

Year: $\quad 2017$

Version:

Please cite the original version:

Mykkänen, M. (2017). Digitaalisen vuorovaikutuksen kulttuuri haastaa poliitikoiden viestintäosaamisen. Prologi : puheviestinnän vuosikirja, 2017, 52-54.

All material supplied via JYX is protected by copyright and other intellectual property rights, and duplication or sale of all or part of any of the repository collections is not permitted, except that material may be duplicated by you for your research use or educational purposes in electronic or print form. You must obtain permission for any other use. Electronic or print copies may not be offered, whether for sale or otherwise to anyone who is not an authorised user. 


\title{
Kirja-arvio
}

Prologi - puheviestinnän

\section{Digitaalisen vuorovaikutuksen kulttuuri haastaa poliitikoiden viestintäosaamisen}

\author{
Markus Mykkänen \\ nuorempi tutkija, FM \\ Jyväskylän yliopisto, Kieli- ja viestintätieteiden laitos \\ markus.mykkanen@jyu.fi
}

Pekka Isotalus, 2017. Mediapoliitikko. Gaudeamus, 247 sivua.

Poliitikolta vaadittava viestintäosaaminen on entistä monimuotoisempaa ja viestinnästä on tullut keskeinen osa ammattitaitoa. Näin kiteyttää Tampereen yliopiston puheviestinnän professori ja poliittisen viestinnän dosentti Pekka Isotalus Mediapoliitikko-kirjassaan. Teoksensa avulla hän haluaa kansantajuistaa politiikan medioitumista esitellen sitä poliitikkojen ja yhteiskunnallisen kehityksen näkökulmasta. Isotalus tekee katsauksen kahdenkymmenen viime vuoden ajalla tehtyyn poliittisen viestinnän tutkimukseen. Hän tarkastelee poliittista viestintää eri näkökulmista ja esittelee, millaisin menetelmin tutkimusta on tehty.

Kirja pitää sisällään kahdeksan lukua. Se etenee yhteiskunnallisesta kehityksestä ja politiikan yleisestä medioitumisesta kohti poliittisen viestinnän henkilöitymistä ja privatisoitumis- ta. Teoksen näkökulma politiikkaan on instituutionaalinen sekä pragmaattinen eikä se kirjoittajan omien sanojensa mukaan pyri ymmärtämään yhteiskuntaa tai kulttuuria rakenteellisesti. Kirjan ydinaihe on poliitikkojen henkilökohtainen viestintäosaaminen. Loppuosassa käsitellään muun muassa television vaalikeskusteluja, internetin ja sosiaalisen median käyttöä poliittisessa viestinnässä. Lopuksi Isotalus ennustaa tulevaisuutta mediapoliitikkojen ja medioitumisen kehittymisen osalta. Lähes jokaista lukua täydentää lähikuvassa-osio, jossa esimerkkitapausten avulla kerrotaan poliitikkojen toimimisesta mediassa. 


\section{Medioituminen heijastuu kaikkeen viestintään}

Politiikan tutkimuksen merkittävimpiä kohteita 1990-luvulta lähtien on ollut kasvanut medioituminen. Isotaluksen mukaan se on avaintermi kuvaamaan nykyistä pitkän aikavälin yhteiskunnallista muutosprosessia, jonka myötä mediasta on tullut hyvin vaikutusvaltainen osa yhteiskuntaa. Isotaluksen mukaan medioituminen vaikuttaa kaikkiin politiikan osatekijöihin niin epäsuoraan kuin suoraan. Nykypoliitikon on kyettävä sujuvasti toimimaan median kanssa sekä hallitsemaan erilaiset mediaympäristöt ja sen asettamat vaatimukset. Viestintä 2010-luvulla ei enää ole vain väline poliitikolle, vaan työ itsessään toteutuu viestimällä ja viestintää tarvitaan jatkuvasti. Isotaluksen mukaan paine poliitikon viestinnälliseen osaamiseen on kasvanut, sillä hänen tulee yhtä aikaa kyetä puhuttelemaan äänestäjiä, neuvottelemaan muiden poliitikkojen kanssa, kuuntelemaan lobbareita ja rakentamaan poliittista brändiään.

\section{Poliitikon ja median viha- rakkaussuhde}

Isotalukselle median ja poliitikkojen suhde on kaksijakoinen. Molemmat ovat kriittisiä toistensa toimintaa kohtaan, mutta silti säännöllisesti hyötyvät toisistaan. Tämä riippuvuussuhde on Isotaluksen mukaan medioitumisen mahdollistaja. Media on kiinteästi mukana poliitikon urakehityksessä ja poliitikot ovat oppineet hyödyntämään tätä symbioosia. Media vaatii kärkipoliitikoilta aiempaa vahvempaa viestintäosaamista. Isotaluksen mielestä hyvät mediapoliitikot ovat oppineet hyödyntämään median toimintalogiikkaa edistäessään omia poliittisia ja urapyrkimyksiä. Asiasisällöllä on edelleen väliä, mutta se ei enää ole ainoa tekijä mediassa toimimisessa. Olennaiseksi on tullut se, kuka asian esittää ja miltä se näyttää. Vies- tintä ja media tuovat tunteet mukaan politiikkaan.

Isotalus esittää, että poliitikot käyttävät mediaa tiedon lähteenä sekä oman viestintänsä areenana. Heidän median käyttönsä on sekä passiivista että aktiivista. Pyrkimys on maksimoida positiivinen ja minimoida kielteinen näkyvyys. Media itse nostaa esiin hyvin esiintyviä, karismaattisia poliitikkoja. Samoin se antaa näkyvyyttä enemmän hallitus- kuin oppositiopuolueille. Poliittisten toimijoiden motiiviksi on tullut jatkuva kampanjointi mediassa. Isotalus näkee, että tärkeintä ei lopulta ole se, miten asiat ovat vaan miltä ne näyttävät mediassa.

\section{Medioituminen yleistyy}

Mediasta on tullut vaikutusvaltainen yhteiskunnan eri osa-alueilla. Isotaluksen mukaan viestinnän korostuminen politiikan tekemisessä on alkanut jo 1990-luvulla. Median toimintaan poliitikot ovat sopeutuneet eri tasoilla. Organisaatiot ovat palkanneet viestintäammattilaisia, jotka hoitavat keskitetysti esimerkiksi puolueiden mediasuhteita. Lisäksi puolueet ovat ottaneet politiikkaan mukaan kokeneita median ja viestinnän ammattilaisia varmistaakseen, että median näkökulmat huomioidaan. Näiden lisäksi puoluejohdossa nykyisin korostetaan entistä enemmän henkilöiden media- ja esiintymistaitoja.

Yksi medioitumisen merkittävä kehityssuunta on politiikan ammatillistuminen eli professionalisoituminen. Isotaluksen mielestä tämä ilmenee siten, että politiikka työllistää entistä enemmän viestinnän ja markkinoinnin ammattilaisia. Suomalaisessa kulttuurissa tähän suhtaudutaan edelleen ristiriitaisesti, vaikka se nähdään väistämättömänä kehityksenä kansainvälisestikin. Suomalaisten yleinen asenne medioitumista kohtaan on Isotaluksen mukaan 
kielteinen. Erityisen kielteisesti suhtaudutaan medioitumisen myötä kasvaneeseen politiikan privatisoitumiseen eli median tapaan käsitellä muun muassa poliitikkojen yksityiselämää tai terveyttä. Privatisoituminen tuo toisaalta poliitikon lähemmäs äänestäjää ja tekee hänestä kiinnostavamman.

\section{Monipuolinen katsaus tutkimukseen}

Isotalus luo kirjassaan monipuolisen katsauksen politiikan tutkimukseen, jonka hän katsoo pohjautuvan vahvasti angloamerikkalaiseen politiikan kulttuuriin. Isotalus on itse seurannut ja tutkinut poliittista viestintää 1990-luvun puolesta välistä lähtien ja kirjaan hän on koonnut yhteen useita aiemmin vain englanniksi julkaistuja tutkimusartikkeleita. Nämä tutkimukset avaavat lähemmin monta mielenkiintoista ja tärkeää poliittisen viestinnän ilmiötä. Tutkimuksien yksityiskohtainen avaaminen erottautuu paikoin tyylillisesti muusta kirjan sisällöstä. Siinä missä Isotalus itse kertoo sujuvasanaisesti ja ymmärrettävästi viestinnän merkityksestä politiikassa tai poliitikon toiminnassa, niin tietämyksen syventämiseen tarkoitetut lähikuvassa-luvut hieman rikkovat muutoin tyylillisesti hyvää kokonaisuutta. Välillä ne tuntuvat tutkimusraporttien lyhennelmiltä sekä metodologiakuvauksilta, joissa olisi voinut arvioida kriittisemmin nykyistä viestintäympäristöä. Lähikuvassa-luvut ovat silti tiiviitä tietopaketteja eikä pieni eroavaisuus kerronnallisuudessa häiritse kokonaisuutta.

Kirjan antoisinta sisältöä on Isotaluksen katsaus poliitikkojen henkilökohtaiseen viestintäosaamiseen. Sen tulisi luoda poliitikolle se pohja, jolla kansalaisiin luodaan suhteita, kuunnellaan ja havainnoidaan sekä ollaan heidän kanssaan vuorovaikutuksessa. Henkilökohtainen viestintäosaaminen voidaan Isotaluksen mukaan nähdä henkilökohtaisena resurssina, vuorovaikutuksena sekä yhteiskunnallisena auktoriteettina toimisen näkökulmista. Nämä kolme tasoa osoittavat, kuinka merkittävää viestintäosaaminen on nykypolitiikassa ja yhteiskunnallisessa vaikuttamisessa. Vanhoja hyviä aikoja kaipaavia Isotalus muistuttaa, että verkkoviestintä on tullut jäädäkseen poliittiseen viestintään. Verkkoviestinnän ja sosiaalisen median merkitys kasvaa suuremmaksi, samalla kun median yleisöt pirstaloituvat entisestään.

\section{Retoriikasta monipuoliseen vuorovaikutukseen}

Kokonaisuudessaan Isotaluksen teos on ajankohtainen ja sujuvasanainen yleisteos viestintäosaamisen merkityksestä politiikassa. Kirja tarjoaa myös suuntaviivoja tulevaisuuteen, vaikka sen keskeisintä antia onkin nykyhetki. Isotaluksen motiivi kirjan kirjoittamiseen on ollut antaa niin poliitikoille, medialle kuin suurelle yleisölle näkökulmia tarkastella, kuinka medioitumiseen tulisi suhtautua. Medioituminen on osa yhteiskunnan kehitystä ja politiikka ei voi olla irrallinen osa tätä kehitystä. Medioitumisen myötä poliitikkojen on omaksuttava uusia viestintätapoja aiemmin korostettujen retoristen taitojen sekä median kanssa yhteistyössä toimimisen lisäksi. 2010-luvun poliitikon repertuaarissa korostuvat monipuoliset vuorovaikutustaidot, jotka yllälueteltujen lisäksi kattavat myös sosiaalisen median ja alati kehittyvät uudet viestintäteknologiat. Isotaluksen mielestä viestinnän uusi aikakausi politiikassa ei kuitenkaan automaattisesti syrjäytä vanhaa teknologiaa tai osaamista. Viestintä ei ole poliitikolle enää väline menestyä, vaan se on kiinteä osa poliittista ammattitaitoa. Isotalus tiivistää: elämme digitaalisen vuorovaikutuksen kulttuurissa, jossa viestintäosaamisen on oltava entistä monipuolisempaa. 